\title{
PENGEMBANGAN PERANGKAT PEMBELAJARAN IPS DENGAN METODE SAINTIFIK UNTUK MENINGKATKAN KEMAMPUAN BERPIKIR KRITIS SISWA MATERI GLOBALISASI DI SEKOLAH DASAR
}

\author{
${ }^{1}$ Muhammad Ilham, ${ }^{2}$ Waode Eti Hardiyanti \\ 1muhammadilham@iainkendari.ac.id, ${ }^{2}$ waode@ung.ac.id \\ ${ }^{1}$ Institut Agama Islam Negeri Kendari, ${ }^{2}$ Universitas Negeri Gorontalo
}

\begin{abstract}
ABSTRAK
Penelitian ini dilatarbelakangi tidak adanya Perangkat Pembelajaran IPS yang berorientasi pada pengembangan kemampuan berpikir siswa. Tujuan penelitian adalah mengkaji perangkat pembelajaran yang digunakan guru dalam mengajarakan materi globalisasi, mengembangkan perangkat pembelajaran IPS dengan metode saintifik, dan mengkaji keefektifan dan kepraktisan perangkat pembelajaran IPS dengan metode saintifik. Penelitian ini merupakan penelitian pengembangan. Teknik pengumpulan data dilakukan dengan observasi, wawancara, tes angket, dan dokumentasi. Analisis kevalidan perangkat pembelajaran dilakukan dengan penilaian ahli. Data tentang sikap kritis siswa dalam proses pembelajaran dianalisis secara deskriptif kualitatif. Analisis kemampuan berpikir kritis siswa meliputi uji normalitas, uji kesamaan dua varians, uji ngain, dan uji perbedaan dua rata-rata. Analisis kepraktisan perangkat pembelajaran dilakukan secara deskriptif kualitatif. Hasil penelitian ditemukan bahwa perangkat pembelajaran yang digunakan guru dalam mengajarkan materi globalisasi berbasis pada transformasi ilmu pengetahuan. Perangkat pembelajaran IPS dengan metode saintifik telah memenuhi kriteria valid. Nilai rata-rata kemampuan berpikir kritis siswa lebih dari KKM (65), uji N-gain dengan nilai 0,50, rata-rata sikap kritis siswa 30,9, dan respons positif guru dan siswa lebih dari $75 \%$. Berdasarkan hasil penelitian tersebut dapat disimpulkan perangkat pembelajaran IPS dengan metode saintifik valid, efektif dan praktis untuk meningkatkan kemampuan berpikir kritis siswa. Sehingga disarankan penggunaan perangkat pembelajaran ini dalam mengajarkan IPS di sekolah dasar.
\end{abstract}

Kata Kunci: Perangkat Pembelajaran IPS, Metode Saintifik, Berpikir Kritis

THE DEVELOPMENT OF SOCIAL STUDIES LEARNING DEVICES WITH

SCIENTIFIC METHOD TO IMPROVE CRITICAL THINKING OF ELEMENTARY SCHOOL STUDENT ON THE TOPIC OF GLOBALIZATION

\author{
${ }^{1}$ Muhammad Ilham, ${ }^{2}$ Waode Eti Hardiyanti \\ 1'muhammadilham@iainkendari.ac.id, ${ }^{2}$ waode@ung.ac.id \\ ${ }^{1}$ Institut Agama Islam Negeri Kendari, ${ }^{2}$ Universitas Negeri Gorontalo
}

\begin{abstract}
The unavailability of IPS learning tool orienting to improve students' skills in thinking requires this research to do. The purpose of this study is to assess the social studies learning tool used in teaching globalization; to develop scientific IPS learning-tool, and to assess the effectiveness and practicality of the scientific IPS learning-tool. This research is a type of Research and Development. Data collection techniques are observation, interview, questionnaire
\end{abstract}

12 | Jurnal Ilmiah “Pendidikan Dasar” Vol. VII No. 1 Januari 2020 
test, and documentation. Analysis of learning tool validity is based on an expert assessment. Analysis of students' critical thinking includes normality test, equality test of two variances, $n$-gain test, and average difference test. Analysis of the learning tool practicality and student's critical attitude data are descriptive qualitative. Results of the study found that IPS learning tool used in teaching globalization based on knowledge transformation. Learning tool development has valid criteria. Student's critical thinking score exceeds KKM (65); $N$-gain score is 0,50; student's critical attitude is 30,09; and teacher and student's response exceeds 75\%. Based on these results we can conclude that scientific IPS learning-tool is valid, effective and practical to improve students' critical thinking skills. So it is recommended to use of this learning tool in teaching social studies in elementary school.

Keyword: IPS Learning Tool, Scientific Method, Critical Thinking

\section{PENDAHULUAN}

Karakteristik materi globalisasi yang memberikan perubahan yang besar pada nilainilai yang diyakini oleh masyarakat mengharuskan pembelajaran di sekolah mengintegrasikan aspek berpikir kritis. Tujuannya agar siswa tidak langsung menerima suatu nilai atapun budaya yang berasal dari negara lain, tetapi menyaringya secara kritis sehingga dapat memisahkan antara nilai yang sesuai dengan kepribadian bangsa dan yang tidak. Berpikir kritis berarti berpikir secara analitis dan reflektif terhadap suatu objek atau fenomena yang diamati. Objek atau fenomena tersebut akan diterima kebenarannya apabila terdapat bukti yang menguatkannya. Ennis dalam Presseisen (1986:21) mengungkapkan Critical thinking is reflective and reasonable thinking that is focused on deciding what to believe or do.

Hasil wawancara tanggal 25 Agustus 2014 pada beberapa guru kelas VI SDN 13 Poasia kota Kendari terungkap bahwa kemampuan berpikir kritis siswa rendah pada materi globalisasi. Keterangan dari masing- masing guru kelas VIA dan VIB menyebutkan saat kegiatan pembelajaran berlangsung hanya terdapat 1 sampai 2 siswa yang berani mengajukan pertanyaan, siswa cenderung diam dan pasif mendengarkan penjelasan guru. Selain itu tidak terlihat siswa yang menyanggah pendapat teman kelasnya pada kegiatan diskusi.

Upaya untuk meningkatkan kemampuan berpikir kritis siswa telah banyak dilakukan guru, salah satunya dengan membuat perangkat pembelajaran yang baik. Namun selama ini perangkat pembelajaran materi globalisasi hanya mengembangkan kemampuan kognitif siswa pada tingkat rendah. Hal ini diperkuat dengan hasil pengamatan peneliti tanggal 26 Agustus 2014 di SDN 13 Poasia kota Kendari yang menunjukkan bahwa dari 2 guru kelas VI SD yang diamati, semuanya hanya membuat perangkat pembelajaran sederhana yang hanya berorientasi pada kemampuan kognitif siswa tingkat rendah.

Metode saintifik merupakan salah satu pengembangan pembelajaran yang berakar pada teori belajar konstruktivis, dimana dalam 
teori belajar ini siswa dipandang sebagai individu yang mampu mengkonstruksi pengetahuan secara mendiri. Metode saintifik dengan kegiatan pembelajarannya yang terdiri dari mengamati, menanya, mengumpulkan data, mengasosiasi, dan mengkomunikasikan tentunya akan memberikan kesempatan yang besar bagi siswa untuk mengembangkan kemampuan berpikir kritis. Hal ini didasari dengan tujuan pembelajaran saintifik yaitu untuk meningkatkan kemampuan intelek, khususnya kemampuan berpikir tingkat tinggi, Hosnan (2014:36).

Hasil penelitian Sasson (2018) dengan judul Fostering the skills of critical thinking and question-posing in a project-based learning environment mengungkapkan bahwa setelah dua tahun penerapan program pembelajaran innovative (pembelajaran berbasis pada penemuan dan konstruktivis) kemampuan berpikir kritis siswa terbukti menunjukkan trend postifif. Penelitian Nurul Augustin (2019) yang melihat pengaruh pendekatan saintifik terhadap kemampuan berpikir kritis siswa kelas IV SD II Jatikalang, Sidoarjo menunjukkan bahwa terdapat peningkatan kemampuan berpikir kritis siswa setelah diajarkan dengan pendekatan saintifik dari setiap pertemuan pembelajaran.

Selain itu, hasil penelitian I Ketut Restana Asta (2014), melibatkan 132 sisiwa kelas V SDN 01 Nagasepha dan Sari Mekar yang mengukur perbedaan hasil belajar IPA antara siswa yang diajar dengan pendekatan saintifik dan dengan pendekatan konvensional menunjukkan bahwa terpadat perbedaan yang siginifikan antara kedua kelompok belajar tersebut dan kemampuan berpikir kritis terbukti berkontribusi positif dalam peningkatan hasil belajar IPA siswa.

Berdasarkan uraian di atas maka tujuan dari penelitian ini yaitu: (1) mengkaji model faktual perangkat pembelajaran IPS yang selama ini digunakan guru SD pada materi globalisasi; (2) mengembangkan perangkat pembelajaran IPS dengan metode saintifik; dan (3) mengkaji keefektifan dan kepraktisan perangkat pembelajaran IPS dengan metode saintifik.

\section{Perangkat Pembelajaran}

Perangkat pembelajaran merupakan alat perlengkapan yang dibutuhkan guru saat memberikan pembelajaran. Perangkat pembelajaran yang dikembangkan dalam penelitian ini meliputi silabus, rencana pelaksanaan pembelajaran (RPP), lembar kerja siswa, video pembelajaran, dan perangkat penilaian kemampuan berpikir kritis siswa.

\section{Metode Saintifik}

Metode saintifik merupakan pembelajaran yang berorientasi pada pendekatan ilmiah. McPherson (2001:242) mengungkapkan Scientific method helps us organize our thought to about the scientific process. Sementara itu Gelman and Brenneman dalam Gerde, Schachter, dan Wasik (2013:317) mendeksripsikan metode saintifik yaitu The

14 | Jurnal Ilmiah “Pendidikan Dasar” Vol. VII No. 1 Januari 2020 
Scientific Method is a process for asking and answering questions using a specific set of procedures. This process can be used as a guide to create comprehensive and meaningful science experiences for young children. Engaging children in scientific inquiry using all steps of the scientific method supports children to construct conceptually-related knowledge because at each step children use a variety of skills to discover new information about the concept of study.

Sejalan dengan pendapat tersebut, Hosnan (2014:34) mengungkapkan pembelajaran saintifik merupakan proses pembelajaran yang dirancang sedemikian rupa agar peserta didik secara aktif mengkonstruk konsep, hukum atau prinsip melalui tahapantahapan mengamati (untuk mengidentifikasi dan menemukan masalah), merumuskan masalah, mengajukan atau merumuskan hipotesis, mengumpulkan data dengan berbagai teknik, menganalisis data, menarik kesimpulan dan mengkomunikasikan konsep, hukum atau prinsip yang ditemukan. Sementara itu Sudarwan dalam Majid (2014:96) mengungkapkan bahwa pembelajaran saintifik merupakan cara atau metode pembelajaran yang menonjolkan dimensi pengamatan, penalaran, penemuan, pengabsahan, dan penjelasan tentang suatu kebenaran.

\section{Berpikir Kritis}

Berpikir kritis merupakan keterampilan berpikir tingkat tinggi. Cottrell (2005:2) mengungkapkan bahwa berpikir kritis adalah suatu proses penilaian dengan melibatkan sekumpulan sikap dan kemampuan dasar yaitu: (1) mengidentifikasi pendapat, posisi dan kesimpulan orang lain; (2) mengevaluasi bukti untuk memperoleh pandangan alternatif; (3) menguji suatu pendapat dan bukti secara ilmiah; (4) mampu menemukan hubungan, melihat fenomena dibalik kejadian, dan mengidentifikasi asumsi yang keliru atau kurang benar; (5) mengetahui berbagai metode dalam membuat pemahaman yang dapat dipertimbangkan; (6) memandang masalah dengan cara terstruktur, serta melahirkan logika dan pengetahuan; (7) membuat kesimpulan apakah pendapat tersebut valid dan dapat dipercaya berdasarkan bukti dan asumsi yang logis; dan (8) menyajikan pandangan secara terstruktur, jelas, masuk akal sehingga dapat meyakinkan orang lain. Semantara itu Walsh dan Paul (1986: 8) mengungkapkan bahwa berpikir kritis adalah menginterpretasi, menganalisis, dan mengevaluasi informasi, argument atau pengalaman yang diperoleh melalui sekumpulan sikap (disposition) dan kemampuan (skills) reflektif sehingga membimbing seseorang dalam berpikir, berkeyakinan dan bertindak.

\section{METODE PENELITIAN}

Penelitian ini merupakan jenis penelitian pengembangan. Prosedur pengembangan yang dilakukan terdiri atas tiga tahap yaitu: (1) pendefinisian mencakup studi literatur dan

15 | Jurnal Ilmiah “Pendidikan Dasar” Vol. VII No. 1 Januari 2020 
pengumpulan informasi kondisi awal perangkat pembelajaran, studi lapangan untuk memperoleh data faktual, analisis data yang diperoleh dan analisis kebutuhan akan perangkat pembelajaran IPS; (2) perancangan mencakup peunyusunan model faktual, perancangan model desain; dan (3) pengembangan mencakup validasi perangkat pembelajaran dan uji coba perangkat pembelajaran.

Desain uji coba dalam penelitian ini yaitu menggunakan pretest-posttest control group design. Subjek uji coba terdiri atas dua jenis yaitu: (1) uji coba terbatas pada kelas VI A SDN 08 Baruga berjumlah 12 siswa; dan (2) uji coba lapangan pada kelas VI A SDN 13 Posia berjumlah 29 siswa. Jenis data mecakup data faktual perangkat pembelajaran IPS, data analisis kebutuhan terhadap perangkat pembelajaran IPS, data hasil validasi ahli, dan data keefektifan dan kepraktisan perangkat pembelajaran. Teknik pengumpulan data yaitu wawancara, angket, observasi, dokumentasi, dan tes.

Teknik analisis data yaitu analisis data validasi perangkat pembelajaran; analisis perangkat penilaian kemampuan berpikir kritis berupa uji reliabilitas, tingkat kesukaran, dan daya beda; analisis uji prasyarat berupa uji normalitas dan homogenitas; analisis keefektifan perangkat pembelajaran berupa analisis data hasil kemampuan berpikir kritis, analisis data peningkatan kemampuan berpikir kritis, dan analisis data sikap kritis siswa; dan analisis kepraktisan perangkat pembelajaran berupa analisis data respons guru dan siswa. Kriteria keberhasilan penelitian terdiri atas indikator kevalidan perangkat pembelajaran, skor akhir dari hasil validasi perangkat minimal dalam kategori baik; indikator keefektifan perangkat pembelajaran yaitu nilai rata-rata hasil tes kemampuan berpikir kritis siswa $\geq \mathrm{KKM}$ (65), skor peningkatan kemampuan berpikir kritis $\geq$ kategori sedang, dan skor sikap kritis $\geq$ mulai berkembang; dan indikator kepraktisan perangkat pembelajaran yaitu resposn positif guru dan siswa terhadap perangkat pembelajaran yang dikembangkan $>75 \%$.

\section{HASIL DAN PEMBAHASAN}

\section{Model Faktual Perangkat Pembelajaran}

Kondisi faktual perangkat pembelajaran IPS diperoleh dengan melakukan pengamatan terhadap perangkat pembelajaran yang digunakan guru dalam mengajarkan mata pelajaran IPS di sekolah dasar. Hasil pengamatan peneliti terhadap kondisi awal perangkat pembelajaran dapat dilihat pada Tabel 1.1.

Berdasarkan Tabel 1.1 terungkap bahwa model perangkat pembelajaran IPS yang selama ini digunakan guru kurang dapat mengembangkan kemampuan berpikir kritis siswa. Hal ini disebabkan oleh beberapa hal. Pertama penyusunan silabus beroerientasi pada ketuntatasan materi sehingga membuat guru memiliki peran dominan dalam proses pembelajaran. 
Kegiatan pembelajaran seharusnya memberikan peran besar terhadap siswa dalam memecahkan masalah pembelajaran, dan guru hanya bertindak sebagai mediator dan fasilitator yang siap membantu siswa bila menghadapi permasalahan yang tidak bisa dipecahkan. Pembelajaran yang didominasi oleh guru akan membatasi siswa dalam mengembangkan potensi yang dimilikinya. Slavin dalam Susanto (2014:96) menyatakan agar siswa benar-benar dapat memahami dan dapat menerapkan pengetahuan, mereka harus memecahkan masalah, menemukan segala sesuatu untuk dirinya, dan berusaha dengan susah payah dengan ide-ide.

Kedua perumusan indikator dan tujuan pembelajaran pada silabus dan RPP beroerientasi pada kemampuan kognitif siswa tingkat rendah. Perumusan tujuan dan indikator pembelajaran pada tingkat tinggi bukan berarti bahwa siswa telah mampu memecahkan masalah-masalah kompleks seperti apa yang dilakukan orang dewasa, akan tetapi hal ini hanya merupakan langkah maju agar siswa terbiasa menggunakan kemampuan berpikir tingkat tinggi sehingga kompetensikompetensi yang membutuhkan kemampuan berpikir tingkat tinggi seperti berpikir kritis dapat berkembang. Lipman dalam Daniel dan Auriac (2011:421) mengungkapkan fostering good thinking does not occur through technique, repetition and memorization, but by means of a praxis.

Ketiga metode pembelajaran yang digunakan masih konvensional. Metode konvensional merupakan pembelajaran yang paling popular di kalangan guru. Metode ini biasanya digunakan untuk mengakomodasi jumlah siswa didik yang terlalu banyak.

\section{Tabel 1. Hasil Pengamatan Terhadap Perangkat Pembelajaran}

\begin{tabular}{ccll}
\hline No & Aspek/Perangkat & \multicolumn{1}{c}{ Sub Aspek } & \multicolumn{2}{c}{ Deskripsi } \\
\hline 1 & Silabus & $\begin{array}{l}\text { Indikator pencapaian } \\
\text { kompetensi } \\
\text { Metode Pembelajaran }\end{array}$ & $\begin{array}{l}\text { Berorientasi pada kemampuan kogntif siswa tingkat } \\
\text { rendah. }\end{array}$ \\
& Menggunakan metode konvensional, yang \\
memusatkan peran guru dalam menyampaikan \\
informasi. \\
\end{tabular}

17 | Jurnal Ilmiah "Pendidikan Dasar" Vol. VII No. 1 Januari 2020 


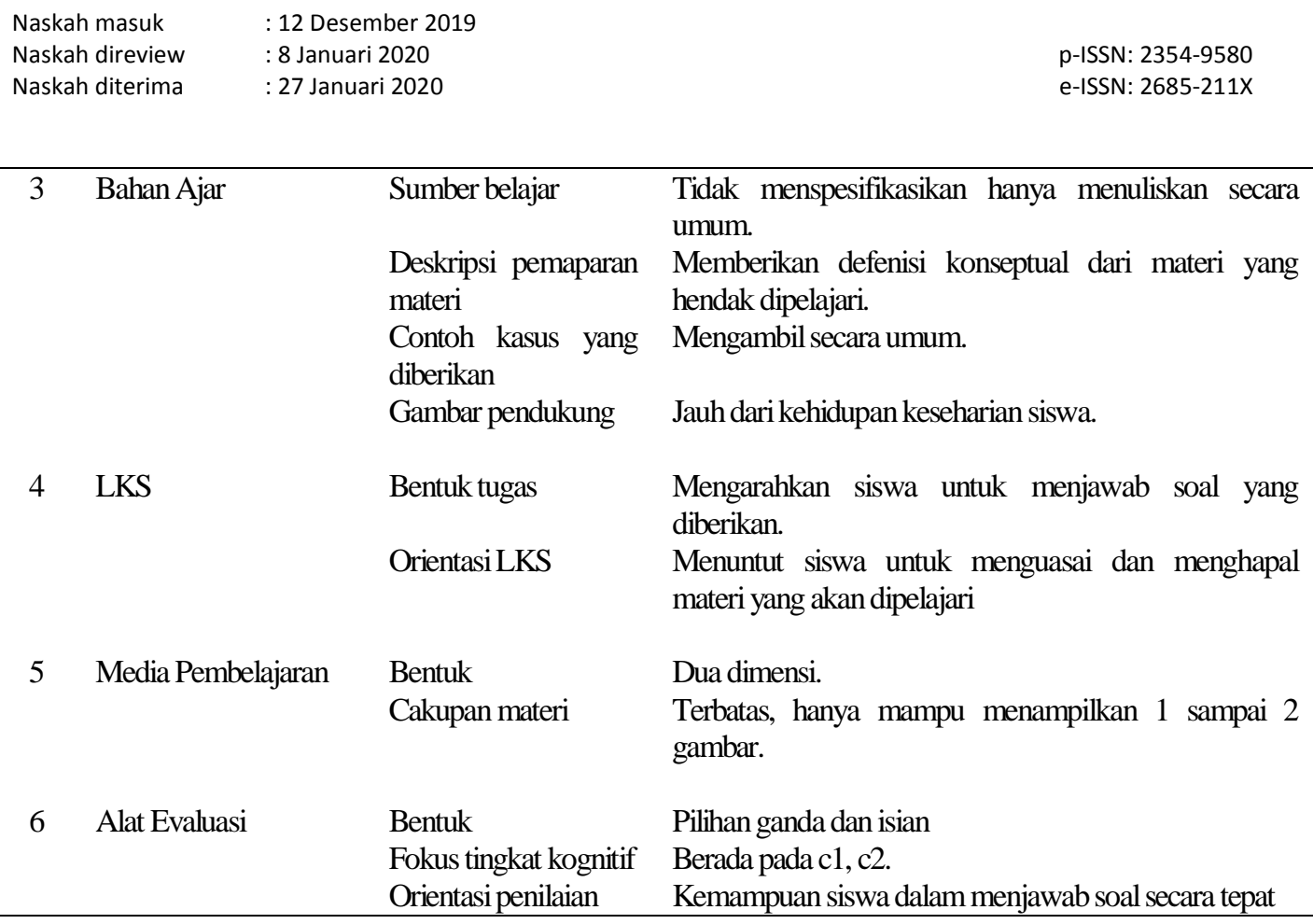

Karena pelaksanaan yang begitu sederhana dan tidak membutuhkan biaya banyak, maka banyak dijadikan pilihan dalam memberikan pembelajaran. Namun metode ini kurang sesuai digunakan untuk mengembangkan kemampuan berpikir siswa. Hal ini disebabkan karena penerapan pembelajaran konvensional kurang memberikan kesempatan yang besar kepada siswa untuk mengeksplorasi kemampuan yang dimiliki. Joyce (2011:10)mengungkapkan peningkatan kemampuan siswa dalam membentuk konsep secara efisien dan meningkatkan jaungkauan persepektif dapat dicapai dengan strategi pembelajaran induktif.

Keempat alat evaluasi yang disusun beroerintasi pada bagaimana siswa menjawab soal secara tepat berdasarkan buku teks dan hanya fokus pada kemampuan kogntif siswa tingkat rendah. Penyusunan alat penilaian yang berorientasi pada kemampuan kognitif tingkat rendah pada dasarnya telah sesuai dengan tingkat perkembangan kemampuan kognitif pada anak sekolah dasar. Namun untuk tujuan tertentu seperti pengembangan kemampuan berpikir kritis siswa maka penyusunan alat penilaian ini perlu sedikit dikurangi. Peningkatan kemampuan berpikir kritis siswa memerlukan keterampilan kognitif tingkat tinggi. Ennis dalam Daniel dan Auriac (2011:418) mengungkapkan bahwa critical thinking as logical thinking characterized by complex cognitive skills. Pendapat lain Lipman dalam Daniel dan Auriac (2011: 420) critical thinking 
presupposes skills that develop according

to four categories: conceptualization, reasoning, generalization and research.

\section{Model Desain Perangkat Pembelajaran dengan Pendekatan Saintifik}

Berdasarkan hasil angket kebutuhan akan perangkat pembelajaran dari empat guru kelas VI SDN 13 Posia dan 8 Baruga, kota Kendari menunjukkan bahwa semua guru merespons bahwa perangkat pembelajaran yang melatih siswa untuk memecahkan masalah secara mandiri sangat dibutuhkan dalam pelajaran IPS materi globalisasi di kelas VI sekolah dasar. Berdasarkan uraian model faktual perangkat pembelajaran IPS dan analisis kebutuhan terhadap perangkat maka disusunlah model desain perangkat pembelajaran IPS dengan metode saintifik seperti pada Tabel 1.2.
Berdasarkan Tabel 1.2 terungkap bahwa Model desain perangkat pembelajaran mengimplementasikan metode saintifik. Motede ini dianggap mampu meningkatkan kemampuan berpikir kritis siswa. Karena skenario pembelajaran melalui metode saintifik memberikan peran yang begitu besar pada peserta didik untuk memecahkan masalah pembelajaran secara mandiri. Abidin (2014:127) mengungkapkan pembelajaran saintifik pada dasarnya adalah pembelajaran yang dilandasi pendekatan ilmiah dalam pembelajaran yang diorientasikan guna membina kemampuan siswa memecahkan masalah melalui serangkaian aktivitas inkuiri yang menuntut kemampuan berpikir kritis, berpikir kreatif, dan berkomunikasi dalam upaya meningkatkan pemahaman siswa.

Tabel 2. Model Desain Pengembangan Perangkat Pembelajaran IPS dengan metode saintifik untuk meningkatkan kemampuan berpikir kritis siswa

\begin{tabular}{ccll}
\hline No & $\begin{array}{c}\text { Pengembangan } \\
\text { Perangkat }\end{array}$ & \multicolumn{1}{c}{ Sub Pengembangan } & \multicolumn{1}{c}{ Deskripsi } \\
\hline 1 & Silabus & $\begin{array}{l}\text { Indikator pencapaian } \\
\text { kompetensi } \\
\text { Metode Pembelajaran }\end{array}$ & $\begin{array}{l}\text { Berorientasi pada kemampuan kogntif siswa tingkat tinggi. } \\
\text { Menggunakan metode saintifik, yang memusatkan peran siswa } \\
\text { dalam memecahkan masalah pembelajaran. } \\
\text { Berorientasi pada kemampuan kognitif siswa tingkat tinggi, dan } \\
\text { melatih siswa untuk berpikir. }\end{array}$ \\
& Penilaian & $\begin{array}{l}\text { Berorientasi pada kemampuan kogntif siswa tingkat tinggi. } \\
\text { Menggunakan metode saintifik, yang memusatkan peran siswa } \\
\text { dalam memecahkan masalah pembelajaran. }\end{array}$ \\
\hline
\end{tabular}

19 | Jurnal Ilmiah "Pendidikan Dasar" Vol. VII No. 1 Januari 2020 


\begin{tabular}{|c|c|c|c|}
\hline & & $\begin{array}{l}\text { Skenario pembelajaran } \\
\text { Penilaian }\end{array}$ & $\begin{array}{l}\text { Skenario pembelajaran disusun secara jelas dan runtut. } \\
\text { Mengukur kemampuan kognitif siswa tingkat tinggi. }\end{array}$ \\
\hline \multirow[t]{5}{*}{3} & Bahan Ajar & Sumber belajar & $\begin{array}{l}\text { Lebih banyak dan buku yang digunakan lebih spesifik, dan } \\
\text { disesuaikan dengan kebutuhan. }\end{array}$ \\
\hline & & $\begin{array}{l}\text { Deskripsi pemaparan } \\
\text { materi }\end{array}$ & $\begin{array}{l}\text { Tidak memberikan defenisi konseptual dari materi yang hendak } \\
\text { dipelajari. }\end{array}$ \\
\hline & & $\begin{array}{l}\text { Contoh kasus yang } \\
\text { diberikan }\end{array}$ & Lebih khusus seputar kehidupan siswa. \\
\hline & & Gambar pendukung & $\begin{array}{l}\text { Diangkat dari kehidupan keseharian siswa. gambar lebih berwarna } \\
\text { dan menarik. }\end{array}$ \\
\hline & & Jenis font & Maliandra \\
\hline \multirow[t]{2}{*}{4} & LKS & Bentuk tugas & $\begin{array}{l}\text { Mengarahkan siswa untuk membuat pertanyaan berdasarkan } \\
\text { materi. }\end{array}$ \\
\hline & & Orientasi LKS & $\begin{array}{l}\text { Menuntut siswa menggunakan kemampuan berpikir dalam } \\
\text { pemecahan masalah }\end{array}$ \\
\hline \multirow[t]{6}{*}{5} & Video & Bentuk & Tiga dimensi \\
\hline & Pembelajaran & Cakupan materi & Lebih luas dan komprehensif. \\
\hline & & Struktur video: & Palino lama 5 menit \\
\hline & & ○ Teks pengiring & Mudah dimengerti, sesuai dengan EYD \\
\hline & & ○ Suara dan music & $\begin{array}{l}\text { Suara mudah didengar, dan musik latar yang digunakan sesuai } \\
\text { dengan tema }\end{array}$ \\
\hline & & ○ Materi/isi video & Penayangan gambar disertai penjelasan. \\
\hline \multirow[t]{7}{*}{6} & Perangkat & TKBK: & \\
\hline & Penilaian & Bentuk & Uraian \\
\hline & Kemampuan & Fokus kognitif & Berorientasi pada $\mathrm{c} 4, \mathrm{c5}$, dan $\mathrm{c} 6$ \\
\hline & Berpikir Kritis & $\begin{array}{l}\text { Orientasi penilaian } \\
\text { LPSK: }\end{array}$ & Kemampuan siswa mengungkapkan pendapat \\
\hline & & Bentuk & Lembar Observasi \\
\hline & & Indikator & Terdiri dari 10 aspek sikap berpikir kritis \\
\hline & & Orientasi penilaian & Pengamatan indikator sikap berpikir kritis \\
\hline
\end{tabular}

Pengintegrasian metode saintifik dalam model desain perangkat pembelajaran IPS hanya dikhususkan pada silabus dan rencana pelakasanaan pembelajaran (RPP), sementara perangkat pembelajaran lainnya seperti bahan ajar, lembar kerja siswa, video pembelajaran dan perangkat penilaian kemampuan berpikir kritis dibuat dengan tujuan untuk mendukung ketercapaian motede saintifik dalam pembelajaran IPS khsusunya pada materi globalisasi.

Model desain bahan ajar didesain untuk mengarahkan siswa menemukan konsep dari materi yang akan dipelajari. Siswa dituntut untuk mengamati suatu kedaaan tertentu kemudian diminta untuk menyimpulkan hasil pengamatan yang telah dilakukan. 
Desain bahan ajar tersebut tentunya tidak hanya melatih kemampuan kognitif siswa tingkat tinggi, tetapi pula melatih sikap siswa dalam memecahkan masalah pembelajaran seperti sabar, tekun, teliti, pantang menyerah dan bersikap terbuka terhadap kemungkinan kebenaran suatu informasi. El-Nemar dalam Joyce (2011:102) mengungkapkan bahwa kurikulum-kurikulum yang berorientasi pada proses pembelajaran induktif berpengaruh positif pada pengembangan keterampilan proses informasi dan sikap siswa terhadap ilmu pengetahuan.

LKS didesain untuk mendukung keterlaksanaan pembelajaran dengan metode saintifik, sehingga soal atau tugas yang harus dikerjakan siswa tidak diberikan, akan tetapi siswa diminta untuk membuat soal sendiri berdasarkan hasil pengamatan yang telah dilakukan. Mengarahkan siswa membuat soal sendiri berarti melatih kemampuan siswa dalam menganalisa permasalahan yang ada. Semakin terlatihnya siswa membuat pertanyaan akan menumbuhkan rasa ingin tahu yang lebih besar siswa terhadap materi pembelajaran. Sehingga akan menumbuhkembangkan minat siswa pada materi yang dipelajari. Abidin (2014:136) mengungkapkan satu dari beberapa fungsi aktivitas bertanya yaitu membangkitkan rasa ingin tahu, minat, dan perhatian siswa tentang suatu topik pembelajaran.

Model desain media pembelajaran berupa video. Penggunaan video pembelajaran tentunya akan memudahkan guru dalam mentransfer informasi yang hendak disampaikan. Selain itu siswa juga akan lebih tertarik untuk mengamati apa yang disampaikan guru sehingga konsep pembelajaran dapat dengan mudah dipahami. Daryanto (2013:90) mengungkapkan beberapa kelebihan digunakannnya media video yaitu: (1) ukuran tampilan video sangat fleksibel dan dapat diatur sesuai dengan kebutuhan; (2) kaya akan informasi dan lugas karena dapat sampai kehadapan siswa secara langsung; dan (3) video menambah satu dimensi baru terhadap pembelajaran.

Model desain perangkat penilaian kemampuan berpikir kritis terdiri atas tes kemampuan berpikir kritis berupa tes uaraian dan lembar pengamatan sikap kritis siswa berupa lembar pengamatan. Tes kemampuan berpikir kritis siswa didesain untuk mengeksplorasi kemampuan siswa dalam berpikir oleh karena itu soal uraian disusun kebanyakan beroerientasi pada kemampuan kognitif 
siswa tingkat tinggi. Pembiasaan siswa

dalam mengerjakan soal-soal dalam

kognitif tingkat tinggi akan

megembangkan kemampuan berpikir

kritis siswa. Cornbleth dalam Walsh dan

Paul (1986:8) mengungkapkan bahwa

berpikir kritis is not limited merely to the evaluation of statements or arguments, as some narrower views have it, but, it involves question raising, seeking information, reasoning, evaluating options, reflecting on one's thinking, and raising and pursuing further questions.

Tabel 3. Soal Kemampuan Berpikir kritis

\begin{tabular}{|c|c|c|c|}
\hline No & $\begin{array}{c}\text { Level } \\
\text { Proses } \\
\text { Kognitif }\end{array}$ & Soal & Indikator Kemampuan Berpikir Kritis \\
\hline 1 & C6 & $\begin{array}{l}\text { Apakah yang kalian ketahui tentang globalisasi? } \\
\text { Cobalah rumuskan maksud dari globalisasi } \\
\text { berdasarkan pemahaman pribadi kalian? }\end{array}$ & Memfokuskan pertanyaan, menganalisis argument \\
\hline 2 & $\mathrm{C} 5$ & $\begin{array}{l}\text { Apakah globalisasi telah masuk di Indonesia? Kalau } \\
\text { iya berikanlah alasan kalian beserta } 2 \text { bukti globalisi } \\
\text { dalam lingkungan masyarakatmu? }\end{array}$ & Memfokuskan pertanyaan, menganalisis argument \\
\hline 3 & $\mathrm{C} 4$ & $\begin{array}{l}\text { Cobalah kalian amati keadaan lingkungan } \\
\text { keluargamu, kemukakanlah } 3 \text { contoh globalisasi yang } \\
\text { kalian temukan? }\end{array}$ & $\begin{array}{l}\text { Bertanya dan menjawab pertanyaan klasifikasi dan } \\
\text { pertanyaan menantang, mengidentifikasi istilah, } \\
\text { mempertimbangkan defenisi, Mengobservasi dan } \\
\text { mempertimbangkan hasil observasi }\end{array}$ \\
\hline 4 & $\mathrm{C} 4$ & $\begin{array}{l}\text { Perhatikan sejenak tentang keadaan lingkungan } \\
\text { sekolahmu, cobalah kalian kemukakan } 3 \text { contoh } \\
\text { globalisasi yang kalian temukan? }\end{array}$ & $\begin{array}{l}\text { Bertanya dan menjawab pertanyaan klasifikasi dan } \\
\text { pertanyaan menantang, mengidentifikasi istilah, } \\
\text { mempertimbangkan defenisi, Mengobservasi dan } \\
\text { mempertimbangkan hasil observasi }\end{array}$ \\
\hline 5 & $\mathrm{C} 4$ & $\begin{array}{l}\text { Perhatikan pula keadaan lingkungan masyarakat di } \\
\text { sekitarmu, cobalah kalian kemukakan } 3 \text { contoh } \\
\text { globalisasi yang kalian identifikasi? }\end{array}$ & $\begin{array}{l}\text { Bertanya dan menjawab pertanyaan klasifikasi dan } \\
\text { pertanyaan menantang, mengidentifikasi istilah, } \\
\text { mempertimbangkan defenisi, Mengobservasi dan } \\
\text { mempertimbangkan hasil observasi }\end{array}$ \\
\hline 6 & $\mathrm{C} 4$ & $\begin{array}{l}\text { Amatilah situasi sosial yang terjadi sebagai akibat } \\
\text { adanya globalisasi dalam lingkungan keluargamu! } \\
\text { Kemukakanlah } 2 \text { keadaan yang bernilai negatif? } \\
\text { Berikan alasanmu! }\end{array}$ & $\begin{array}{l}\text { Memfokuskan pertanyaan, menganalisis argument, } \\
\text { memutuskan suatu tindakan, Mengobservasi dan } \\
\text { mempertimbangkan hasil observasi, Mempertimbangkan } \\
\text { kredibilitas suatu sumber }\end{array}$ \\
\hline 7 & $\mathrm{C} 4$ & $\begin{array}{l}\text { Amati pula situasi sosial yang terjadi sebagai akibat } \\
\text { adanya globalisasi dalam lingkungan sekolah dan } \\
\text { masyarakatmu! kemukakan } 1 \text { diantara dampak } \\
\text { tersebut yang bernilai negatif? Berikan alasanmu! }\end{array}$ & $\begin{array}{l}\text { Memfokuskan pertanyaan, menganalisis argument, } \\
\text { memutuskan suatu tindakan, Mengobservasi dan } \\
\text { mempertimbangkan hasil observasi, Mempertimbangkan } \\
\text { kredibilitas suatu sumber }\end{array}$ \\
\hline 8 & $\mathrm{C} 4$ & $\begin{array}{l}\text { Berdasarkan pengamatan pada lingkungan } \\
\text { masyarakatmu, kemukakan } 2 \text { situasi sosial yang } \\
\text { termasuk dalam dampak positif globalisasi? Berikan } \\
\text { alasanmu! }\end{array}$ & $\begin{array}{l}\text { Memfokuskan pertanyaan, menganalisis argument, } \\
\text { memutuskan suatu tindakan, Mengobservasi dan } \\
\text { mempertimbangkan hasil observasi, Mempertimbangkan } \\
\text { kredibilitas suatu sumber }\end{array}$ \\
\hline 9 & $\mathrm{C} 5$ & $\begin{array}{l}\text { Bagaimanakah sikap kalian terhadap arus globalisasi? } \\
\text { Kemukakan pendapatmu? }\end{array}$ & $\begin{array}{l}\text { Mengidentifikasi asumsi, Membuat/mempertimbangkan } \\
\text { nilai keputusan, membuat induksi dan mempertimbangkan } \\
\text { induksi, }\end{array}$ \\
\hline 10 & $\mathrm{C} 5$ & $\begin{array}{l}\text { Menurut kalian apa yang akan terjadi jika Indonesia } \\
\text { tidak berperan dan tergabung dalam kerjasama } \\
\text { internasional? }\end{array}$ & $\begin{array}{l}\text { Mengidentifikasi istilah, mempertimbangkan defenisi, dan } \\
\text { Mengidentifikasi asumsi, membuat deduksi dan } \\
\text { mempertimbangkan hasil deduksi }\end{array}$ \\
\hline 11 & $\mathrm{C} 4$ & $\begin{array}{l}\text { Menurut anda bagaimana perusahaan asing di } \\
\text { Indonesia dapat berkembang? }\end{array}$ & $\begin{array}{l}\text { Memfokuskan pertanyaan, menganalisis argument, } \\
\text { memutuskan suatu tindakan }\end{array}$ \\
\hline
\end{tabular}




\begin{tabular}{|c|c|c|}
\hline \multicolumn{2}{|c|}{ Naskah masuk } & : 12 Desember 2019 \\
\hline \multicolumn{2}{|c|}{ Naskah direview } & : 8 Januari 2020 \\
\hline \multicolumn{2}{|c|}{ Naskah diterima } & : 27 Januari 2020 \\
\hline 12 & $\mathrm{C} 4$ & $\begin{array}{l}\text { Amatilah dampak yang ditimbulkan dari adanya } \\
\text { perusahaan asing berikut; a) Meningkatkan devisa } \\
\text { negara; b) Memenuhi kebutuhan hidup masyarakat;c) } \\
\text { Mencemari lingkungan; d) Menyediakan lapangan } \\
\text { pekerjaan; e)Mengotori udara melalui asap pabrik; } \\
\text { f)Terjadinya alih fungsi lahan menjadi perumahan. } \\
\text { Berdasarkan dampak dari perusahaan asing di } \\
\text { atas manakah yang bernilai positif? Berikan } \\
\text { alasanmu? }\end{array}$ \\
\hline 13 & $\mathrm{C} 4$ & $\begin{array}{l}\text { Berdasarkan soal nomor } 12 \text {, Manakah pula dari } \\
\text { dampak adanya perusahaan asing di atas yang } \\
\text { bernilai negatif? Berikan alasanmu? }\end{array}$ \\
\hline 14 & $\mathrm{C} 5$ & $\begin{array}{l}\text { Bagaimanakah sikap kalian terhadap keberadaan } \\
\text { perusahaan asing di Indonesia? }\end{array}$ \\
\hline 15 & $\mathrm{C} 5$ & $\begin{array}{l}\text { Bagaimana pula sikap yang harus diambil pemerintah } \\
\text { terhadap keberadaan perusahaan asing di Indonesia? }\end{array}$ \\
\hline
\end{tabular}

Diadopsi dari Ennis dalam Presseisen (1986:21)
p-ISSN: 2354-9580

e-ISSN: 2685-211X
Memfokuskan pertanyaan, menganalisis argument, Memutuskan suatu tindakan, Mempertimbangkan kredibilitas suatu sumber
Lembar pengamatan sikap kritis dibuat sebagai upaya untuk menilai sikap kritis siswa saat dilaksanakan pembelajaran dengan metode saintifik. Penyusunan lembar pengamatan sikap kritis siswa sebagai salah satu instrument penilaian kemampuan berpikir kritis siswa tidak lepas dari konsep dasar berpikir kritis yang terdiri dari dua aspek yaitu kemampuan (skills), dan sikap (disposition).
Memfokuskan pertanyaan, menganalisis argument, Memutuskan suatu tindakan, Mempertimbangkan kredibilitas suatu sumber

Mengidentifikasi asumsi, Membuat dan mempertimbangkan nilai keputusan, membuat induksi dan mempertimbangkan induksi.

Mengidentifikasi asumsi, Membuat dan

mempertimbangkan nilai keputusan, membuat induksi dan mempertimbangkan induksi.

Tabel 4. Indikator Pengamatan Sikap Kritis Siswa

\begin{tabular}{cll}
\hline No & \multicolumn{1}{c}{ Indikator } & \multicolumn{1}{c}{ Deskripsi } \\
\hline 1 & Intellectual Curiosity & $\begin{array}{l}\text { Mencari jawaban dari beberapa pertanyaan dan masalah, menginvestigasi sebab dan gambaran } \\
\text { dari suatu peristiwa melalui pertanyaan bagaimana, mengapa, siapa, kapan, dan dimana. } \\
\text { Menggunakan objektifitas dalam proses pembuatan keputusan. }\end{array}$ \\
2 & Objectivity & Keinginan untuk memikirkan kemungkinan kebenaran dari semua informasi yang ada. \\
3 & Open-Mindedness & Menghindari dari sikap teguh terhadap satu keyakinan, sikap dogmatis, dan kekakuan. \\
4 & Flexibility & Menunda kebenaran sebuah kesimpulan sampai bukti kongkrit telah dihadirkan. \\
5 & Intellectual Skepticism & Menerima kebenaran dari suatu pernyataan ketika telah ada bukti yang cukup meskipun harus \\
6 & Intellectual Honesty & mengubah keyakinan kita sendiri. \\
7 & Being Systematic & Fokus terhadap prosedur penalaran secara konsisten dalam membuat suatu kesimpulan. \\
8 & Persistence & Sabar dalam mencari sebuah pemecahan masalah. \\
9 & Decisiveness & Membuat suatu kesimpulan ketika bukti telah ada. \\
10 & Respectfor other & Keinginan untuk mengakui bahwa kemungkinan pendapatmu itu salah dan pendapat orang lain \\
& viewpoints & lebih benar
\end{tabular}

Paul dalam Auriac dan Daniel (2011:419)

educating toward critical thinking

requires strategies that are both cognitive

(i.e. logical and creative thinking) and

emotional/moral. Tes kemampuan berpikir kritis dan indikator pengamatan

sikap kritis dapat dilihat pada table 1.3

dan 1.4.

23 | Jurnal Ilmiah "Pendidikan Dasar" Vol. VII No. 1 Januari 2020 
Keefektifan Perangkat Pembelajaran dengan Pendekatan Saintifik

Model desain perangkat pembelajaran IPS dengan metode saintifik selanjutnya divalidasi oleh ahli dan praktisi. Hasil validasi ahli dan praktisi merupakan model hipotetik. Hasil validasi model desain perangkat pembelajaran IPS dengan metode saintifik menunjukkan skor akhir (Sa) lebih dari kriteria valid. Perolehan skor silabus yaitu 31,4; rencana pelaksanaan pembelajaran 40,8; bahan ajar, lembar kerja siswa dan video pembelajaran masing-masing yaitu 32,4; 48,8; dan 65,6 ; perangkat penilaian kemampuan berpikir kritis secara berurutan 38, 8 untuk Tes kemampuan berpikir kritis, dan 28,4 untuk lembar pengamatan sikap kritis siswa dan semuanya berada pada kriteria tingkat kevalidan sangat baik.

Hasil uji coba pada skala terbatas menunjukkan bahwa tes kemampuan berpikir kritis memiliki reliabilitas yang baik, daya beda soal tidak ada dalam kategori jelek dan tingkat kesukarannya bervariasi yaitu sukar, sedang dan mudah. Keeffektifan perangkat pembelajaran dilihat dengan menguji soal pretest dan posttest. Hasil pengujian soal diawali dengan uji normalitas dan uji homogenitas.
Hasil uji normalitas menunjukkan bahwa kelas eksperimen dan kontrol sama-sama berdistribusi normal dengan nilai asymp. Sig. (2-tailed) untuk kelas eksperimen 0,518 dan kelas kontrol 0,324 > nilai signifikansi $\alpha=0,05$. Hasil uji homogenitas menunjukkan bahwa antara kelas eksperimen dan kelas kontrol homogen dengan nilai asymp. Sig. (2tailed) $0,859>$ nilai signifikansi $\alpha=0,05$. Hasil uji perbedaan rata-rata soal pretest diketahui bahwa nilai $\mathrm{t}_{\text {hitung }}=0,144<\mathrm{t}_{\text {tabel }}$ $(56 ; 0,05)=1,673$ (two tailed) yang berarti $\mathrm{H}_{\mathrm{o}}$ diterima, artinya rata-rata pretest kelas eksperimen dan kelas kontrol adalah sama, sehingga siswa antara kelas eksperimen dan kelas kontrol memiliki kemampuan yang sama. Uji hasil kemampuan berpikir kritis soal posttest menunjukkan nilai thitung pada baris pertama Equal Variances Assumed yaitu $\mathrm{t}_{\text {hitung }}=2,785>\mathrm{t}_{\text {tabel }}$ $(56 ; 0,05)=1.673$ yang berarti $H_{o}$ ditolak, artinya rata-rata posttest kelas eksperimen dan kelas kontrol adalah berbeda. Hasil uji beda rata-rata pada data posttest menunjukkan bahwa perangkat pembelajaran IPS dengan metode saintifik dapat meningkatkan kemampuan berpikir kritis siswa.

Besarnya peningkatan kemampuan berpikir kritis siswa dilihat 
dengan uji N-Gain. Hasil uji N-Gain kelas eksperimen adalah 0,50 dengan kategori sedang. Sedangkan untuk kelas kontrol nilai $\mathrm{N}$-Gain sebesar 0,28 dalam kategori rendah. Sehingga dapat diindikasikan bahwa model hipotetik perangkat pembelajaran IPS dengan metode saintifik terbukti dapat meningkatkan kemampuan berpikir kitis siswa. Hal ini sejalan dengan penelitian Chen (2015) bahwa penggunaan pembelajaran penemuan saintifik dengan diintegrasikan penalaran ilmiah terbukti efektif dalam meningkatkan kemampuan dalam menguji hipotesis, membenarkan hipotesis, dan pemahaman yang didasarkan pada bukti yang benar.

Ketuntasan kemampuan berpikir kritis diuji menggunakan uji one sample $t$ test dengan KKM 65. Hasil uji ketuntasan kemampuan berpikir kritis siswa diperoleh nilai thitung $=2,276>t_{\text {table }}(28 ; 0,05)=1,701$ maka $\mathrm{H}_{\mathrm{o}}$ ditolak, sehingga dapat disimpulkan bahwa hasil peningkatan kemampuan berpikir kritis lebih dari KKM (65). Hasil ini sejalan dengan penelitian Machin (2014) bahwa penerapan pembelajaran saintifik berpengaruh posifitif terhadap peningkatan hasil belajar kognitif, afektif dan psikomotorik dan telah mencapai ketuntasan klasikal yang ditetapkan.

Indikator keefektifan perangkat pembelajaran selanjutnya adalah sikap kritis siswa. Hasil pengamatan sikap kritis siswa menunjukkan skor rata-rata kelas eksperimen dalam tiga kali pertemuan secara berurutan adalah $30 ; 30,2$; dan 32,4 $\geq$ Mulai berkembang $(25,0 \leq \mathrm{S}<32,5)$. Sementara di kelas kontrol secara berurutan adalah 23,9; 24,2; dan 24,4 < mulai berkembang $(25,0 \leq \mathrm{S}<32,5)$. Hasil uji perbedaan rata-rata Mann Whitney U Test diperoleh Sig. $0,000<\alpha=$ 0,05 sehingga $\mathrm{H}_{0}$ ditolak. Dapat disimpulkan bahwa skor sikap kritis siswa kelas eksperimen lebih tinggi dibanding dengan skor sikap kelas kontrol. Perbedaan skor sikap kritis siswa antara kelas eksperimen dan kelas kontrol terjadi karena skenario pembelajaran yang diterapkan dari kedua kelas berbeda. Dominasi siswa dalam kegiatan belajar mengajar kelas eksperimen lebih terlihat dibandingkan kelas kontrol. Majid (2014:97) mengungkapkan pendekatan ilmiah (scientific) diyakini dapat mengembangkan sikap, keterampilan, dan pengetahuan siswa. 
Kepraktisan Perangkat Pembelajaran dengan Pendekatan Saintifik

Tingkat keberhasilan penelitian selanjutnya adalah kepraktisan pembelajaran. Respons empat orang guru terhadap perangkat pembelajaran IPS dengan metode saintifik sangat positif. Guru A memberikan skor 92,3, guru B memberikan skor 76,9, guru C memberikan skor 84,6, dan guru D memberikan skor 88,5. Rata-rata skor respons keempat guru tersebut adalah 85,6 yang termasuk dalam kategori sangat baik. Sehingga dapat disimpulkan bahwa perangkat pembelajaran IPS dengan metode saintifik direspons positif oleh guru. Respons siswa berada pada jenjang sangat baik dengan rentang skor $(75 \% \leq$ $\mathrm{Sa} \leq 100 \%$ ). Perolehan skor rata-rata keseluruhan respons siswa yaitu 83,2\% yang termasuk dalam kategori sangat baik, yang berarti perangkat pembelajaran IPS dengan metode saintifik direspons positif oleh siswa. Berdasarkan perolehan skor respons guru dan siswa dapat disimpulkan bahwa indikator ketercapaian kpraktisan pembelajaran telah diperoleh. Sehingga perangkat pembelajaran IPS dengan metode saintifik praktis digunakan dalam kegiatan belajar mengajar. Hal ini senada dengan penelitian yang dilakukan oleh
Putrawan (2014) yang menemukan bahwa pengembangan perangkat pembelajaran dengan pendekatan saintifik direspons positif oleh siswa dan guru setelah dilaksanakannya pembelajaran sehingga memenuhi kriteria praktis.

Berdasarkan hasil uji skala terbatas dan uji skala luas, maka dapat disimpulkan bahwa model hipotetik perangkat pembelajaran IPS dengan metode saintifik efektif dan praktis dalam meningkatkan kemampuan berpikir kritis siswa di sekolah dasar. Hasil uji skala terbatas dan skala luas model hipotetik perangkat pembelajaran IPS dengan metode saintifik menghasilkan model final perangkat pembelajaran IPS dengan metode saintifik untuk meningkatkan kemampuan berpikir kritis siswa sekolah dasar.

\section{SIMPULAN}

Model faktual perangkat pembelajaran IPS yang digunakan guru di kelas VI SD belum mampu meningkatkan kemampuan berpikir kritis siswa karena penyusunan silabus beroerientasi pada ketuntatasan materi, indikator dan tujuan pembelajaran disusun dengan berorientasi pada kemampuan kognitif siswa tingkat rendah, metode pembelajaran yang 
digunakan masih konvensional, dan alat evaluasi yang disusun beroerintasi pada bagaimana siswa menjawab soal secara tepat berdasarkan buku teks.

Desain perangkat pembelajaran IPS dengan metode saintifik didasarkan pada analisis model faktual dan kebutuhan guru terhadap perangkat pembelajaran di sekolah dasar. Model desain perangkat pembelajaran selanjutnya divalidasi oleh lima orang ahli. Hasil validasi model desain perangkat pembelajaran menunjukkan skor akhir (Sa) lebih dari kriteria valid.

Perangkat pembelajaran IPS dengan metode saintifik efektif dalam meningkatkan kemampuan berpikir kritis siswa dengan ketuntasan kemampuan berpikir kritis lebih dari nilai KKM 65 dan rata-rata 72,0, uji gain dengan nilai 0,50 dalam kategori sedang dan perolehan skor sikap kritis siswa 30,9 dengan kategori mulai berkembang. Skor akhir respons guru dan siswa terhadap perangkat pembelajaran IPS dengan metode saintifik lebih dari $75 \%$ dengan masing-masing skor respons guru dan siswa yaitu $85,6 \%$ dan $83,2 \%$, sehingga perangkat pembelajaran IPS dengan metode saintifik praktis digunakan dalam meningkatkan kemampuan berpikir kritis siswa.
Berdasarkan hasil penelitian ini dan kajian dari beberapa peneltian yang dilakukan sebelumnya dapat dilihat bahwa penelitian yang mengembangkan kemampuan berpikir kritis melalui pendekatan saintifik masih lebih fokus pada siswa kelas tinggi di sekolah dasar. Oleh karena itu penelitian selanjutnya lebih diharapkan memusatkan pada pengembangan kemampuan berpikir kritis kelas rendah di sekolah dasar.

\section{DAFTAR PUSTAKA}

Abidin Y. 2014. Desain Sistem Pembelajaran dalam Konteks Kurikulum 2013. Bandung : Refika Aditama.

Agustin N. 2019. Pengaruh Pendekatan Saintifik Terhadap Keterampilan Berpikir Kritis Siswa Subtema Keberagaman Makhluk Hidup di Lingkunganku Kelas IV Sekolah Dasar. Child Education Journal, 1(1), 36-43

Asta, R. K. I \& Agung G. A. A. 2015. Pengaruh Pendekatan Saintifik dan Kemampuan Berpikir Kritis terhadap Hasil Belajar IPA. Jurnal Mimbar PGSD Undiksha, 3 (1),

Chen \& She. 2015. The effectiveness of Scientific Inquiry with/without Integration of Scientific Reasoning. International 
Journal of Science \& Mathematics Education. 13 (1):1-20.

Cottrell, S. 2005. Critical Thinking Skills: Developing Effective Analysis and Argument. New York: Palgrave Macmillan.

Daniel, M. F., \& Auriac, E. 2011. Philosophy, Critical Thinking, and Philosophy for Children. Educational Philosophy and Theory Journal, 43(5):415-435.

Daryanto. 2013. Media Pembajaran: Perannya Sangat Penting dalam Mencapai Tujuan Pembelajaran. Yogyakarta: Gava Media.

Gerde, H.K., Schachter. R.E., Wasik. B.A. 2013. Using the Scientific Method to Guide Learning: An Integrated Approach to Early Childhood Curriculum. Early Childhood Education Journal,41:315-323.

Hosnan, M. 2014. Pendekatan Saintifik dan Kontekstual dalam Pembelajaran Abad 21. Bogor : Ghalia Indonesia

Joyce, B., Weil, M., \& Calhoun, E. 2011. Models of Teaching. Yogyakarta: Pustaka Pelajar.

Machin, A. 2014 Implementasi Pendekatan Saintifik, Penanaman Karakter dan Konservasi pada Pembelajaran Materi Pertumbuhan. Jurnal Pendidikan IPA Indonesia, 3 (1): 28-35.
Majid. 2014. Impelemetnasi Kurikulum 2013: Kajian Teoritis dan Praktis. Yogyakarta: Insan Madani.

McPherson, G.R. 2001. Teaching and Learning The Scientific Method. The American Biology Teacher Journal, 63 (4): 242-245.

Presseisen, B. Z . 1986. Critical Thinking and Thinking Skills: State of The Art Definitions and Practice in Public Schools. Philadelphia, Pa: Institution Research For Better Schools, Inc.

Putrawan, A. A dan Suharta, I.G. 2014. Pengembangan Perangkat Pembelajaran Matematika dengan Pendekatan Scientific Berbantuan Geogebra dalam Upaya Meningkatkan Keterampilan Komunikasi dan Aktivitas Belajar Matematika Siswa Kelas VIII SMP. Jurnal Pendidikan Matematika. 3(1): 1-13.

Sasson I, Yehuda I, \& Noam Malkinson. 2018. Fostering the skills of critical thinking and question-posing in a projectbased learning environment. Jurnal Elsevier, 29, 203-2012.

Susanto, A. 2013. Teori Belajar dan Pembelajaran di Sekolah Dasar. Jakarta: Kencana.

Walsh, Debby \& Paul, W. Richard. 1986. The Goal of Critical Thinking from Educational Ideal to Educational Reality. Chicago: American Federation of 
Teacher Educational Issues

Department.

29 | Jurnal Ilmiah “Pendidikan Dasar” Vol. VII No. 1 Januari 2020 